\title{
Governable Stacks against Digital Colonialism
}

\author{
Nathan Schneider \\ University of Colorado Boulder, Boulder, Colorado, USA, \\ nathan.schneider@colorado.edu, https://nathanschneider.info
}

\begin{abstract}
Critics have been converging around the logic of colonialism to describe the Internet economy. If we are serious about the laden language of the colonial, we should be ready to learn from struggles against pre-digital empires and colonial regimes. Although acts of insurrection may attract more attention, one thing leaders and theorists of anticolonial resistance have stressed persistently is the centrality of self-governance in everyday life as both a means and an end of their movements. But the dominant platforms for online communities are not well suited for durable self-governing. Resistance often relies on the same colonial firms it opposes. What would community-governed technologies look like? This article introduces the concept of "governable stacks", a framework for self-governing as resistance to digital colonialism.
\end{abstract}

Keywords: decoloniality, digital colonialism, governance, governmentality, social media

Acknowledgement: I am grateful for substantive feedback on earlier drafts from Nabil Echchaibi, Adriana Garriga-López, Priya Krishnamoorthy, Morshed Mannan, Neil Mather, Yates McKee, Bo Waggoner, and Aparna Subramanyam, as well as anonymous reviewers.

\section{Introduction}

Critics have been converging around the logic of colonialism to describe the Internet economy, in various terms: digital colonialism (Jandrić and Kuzmanić 2016; Pinto 2018; Kwet 2019; Avila 2020), technocolonialism (Madianou 2019), data colonialism (Thatcher, O'Sullivan and Mahmoudi 2016; Couldry and Mejias 2019b), data orientalism (Kotliar 2020), digital capitalism (Qiu 2017), digital extractivism (lyer et al. 2021), platform imperialism (Jin 2013), postcolonial computing (Irani et al. 2010), decolonial computing (Ali 2016), or imperial play (van der Merwe 2020), for example. Computing, writes Syed Mustafa Ali (2016), "is colonial through and through". Stefano Harney and Fred Moten $(2013,87)$ identify a lineage from the Atlantic slave trade to the packetswitching of ARPANET: "the dream of this newly dominant capitalist science" in which containerised logistics packages every part of life into the possibility of being "shipped". Less developed than the critiques, however, are the means of resistance. This article explores one such strategy: the practice of self-governance in relationship to technology.

I will use digital colonialism as a capacious shorthand for the above terms - emerging forms of abuse by governments and corporations through their control over Internet technologies.

If we are serious about the laden language of the colonial, we should be ready to learn from struggles against pre-digital empires and colonial regimes. This means recognising the danger of context collapse through "leapfrogging", as Frederick Cooper (2005) puts it, when applying the language of military domination to feats of data extraction and digital labour arbitrage. In the apt phrase of Eve Tuck and K. Wayne Yang (2012), "decolonization is not a metaphor". To name the colonial is a call to conflict. 
Theorists and practitioners of anticolonial resistance have persistently stressed the centrality of self-governance in everyday life as both the means and the end of their movements, alongside acts of outright insurrection. By self-governance I mean to evoke other terms like autonomy, autogestión, autogestió, community control, self-determination, self-management, self-organising, self-rule, sovereignty, swaraj, and more - together encompassing how groups of people become impervious and intolerable to those who want to govern them by governing themselves. The aspiration to be "ungovernable" has appeared among thinkers ranging from the philosophers Michel Foucault and Giorgio Agamben (Thaning, Gudmand-Høyer and Raffnsøe 2016) to former Black Panther Lorenzo Kom'boa Ervin (Anderson 2020), each seeking to assert the vital personhood of people caught in dehumanising systems. Such systems utilise "governmentality" to extend their power into subjects' lives (Li 2007). Scholars of governance tend to regard it as something done to - or at best, for - most people, rather than something they do themselves (Levi-Faur 2012). Self-governance against colonialism is something else, something people do to govern while becoming ungovernable.

To become ungovernable under digital colonialism, how should we be learning to self-govern?

I pose this question while observing that the platforms most available for online organising are not well-suited for self-governing; tools for basic group decision-making are not widespread, and nor are mechanisms to hold those in authority accountable (Schneider 2021). The design of social platforms inclines toward enabling the governmentality of platform owners, aided by their user-administrator proxies, rather than user governance that could turn against the owners' interests. Campaigns of digital resistance often employ the same colonial firms they oppose. Those confronting digital colonialism today might therefore orient their struggles, as past anticolonial movements have, by rediscovering and reinventing the art of self-governance.

Settler colonialism and digital "user experience" both involve what legal scholar Sanjukta Paul (2020) calls the "allocation of coordination rights". Regimes dictate who has the right to self-organise, or not, and under what conditions. Micro-targeted discrimination singles out individuals for exposure to exploitative advertising, stifling public outcry (Benjamin 2019). Algorithmic decisions about public-service provision make it harder for harmed communities to put collective pressure on individual decision makers (Eubanks 2018). Humanitarian organisations collect data about refugees, which the refugees themselves cannot access while the organisations use it for future fundraising (Madianou 2019). Individual users might have options on a platform to access or delete their own personal data, yet platform companies alone can develop products from the users' data in the aggregate (Couldry and Mejias 2019a). Platforms impose the developers' cultural norms, projecting a false universality that leaves little space for user communities to practice their own cultures (Kwet 2019; Milan and Treré 2019; Duarte et al. 2019). And at least as much as platforms might enable activist organising, they introduce new varieties of surveillance and repression (Tufekci 2017; Canella 2018).

"Governance is what we are fighting for", writes Black Lives Matter co-founder Alica Garza $(2020,273)$. "We are fighting for the right to make decisions for our own lives and to ensure that right for others". Her movement's protests have made whole sections of cities ungovernable through daring, fraught, fleeting attempts to implement alternatives to policing. Progress goes slowly, with setbacks and blowback, until seemingly all at once even those in power no longer have any choice but to build on the fragile experiments from the streets. 
What would community-governed technologies look like, and how can they resist exploitation? I introduce the concept of "governable stacks" as a means of ungovernable organising under digital colonialism. From here, this article reviews how anti-colonial leaders and thinkers have thought about self-governance. It then turns to the perils of recent failures among resistance movements to self-govern under digital colonialism. The following two sections present governable stacks in detail as a concept and as a practice.

\section{The Trouble of Governance}

"Governance is the extension of whiteness on a global scale", write Stefano Harney and Fred Moten $(2013,56)$. NGOs are the "laboratories" of governance, which turns democracy into labour. It is a cheap sort of domination because the subjects do it to themselves: "Governance arrives to manage self-management, not from above, but from below" (55). Harney and Moten reply with a politics of refusal and "being without interests", a call to imagine what it would mean "to struggle against governance" (57): "We are the general antagonism to politics looming outside every attempt to politicise, every imposition of self-governance" (20).

Harney and Moten's polemic can claim many ancestors. They cite Frantz Fanon, who stressed the "spontaneity" of popular uprisings, the ungovernable reaction of the lumpen-proletariat, "the most spontaneous and the most radically revolutionary forces of a colonized people" (Fanon 1961/1963, 81). They celebrate the ungovernable villages of escaped slaves in the Americas, including the maroons of Saint-Domingue's high hills, whose raids did not wait for Touissant Louverture's command but made possible the eventual independence of Haiti (Lebrón Ortiz 2020).

"You know, I love C.L.R. James", says Moten in passing (Harney and Moten 2013, 155). James, the Trinidadian chronicler of Louverture's revolution and an instigator of others from Tanzania to Detroit, praised spontaneity as well. His book with Grace Lee Boggs and Pierre Chaulieu, Facing Reality, describes a "most conscious and finished opposition to the parliamentary procedure" found among dockworkers. By their account, "dockers do not like votes"; "they sense the general sentiment and act on that" (James, Lee and Chaulieu 1958/1974, 121-122). What holds sway is a worker's je ne sais quoi ability to capture the attention of the others, regardless of role or position: decision without institution.

The age of networks has only deepened the allure of spontaneity among radical theorists, as with Michael Hardt and Antonio Negri's admiration for the "multitude" and the "assembly" against fixed organisational forms (2017), or Manuel Castells's (2015) "networks of outrage and hope". Underground tracts from such pseudonymous figures as the Invisible Committee (2009) and the Vitalist International (2019) long for rebellions whose disorder is their vindication, while adrienne maree brown (2017) presents spontaneous self-organisation in nature as a theory of social change. Each seems to profess that organisational forms of revolutions past no longer compute - in part because we now have computers.

An antithesis: over a century ago, Vladimir Lenin (1902/1961) regarded those "who kneel in prayer to spontaneity" as a "fungus" among revolutionaries. Where there is spontaneity among the masses, it obtains power only through an organised and disciplined vanguard party, such as the one he would lead in Russia. Rosa Luxemburg (1904) recoiled at the rigidity of Lenin's vanguard, one moulded by the discipline of the factory, the army, and the bureaucracy. She called for a movement that would be "supple as well as firm", capacious enough to hold the full humanity of its participants. Yet a communist regime came to pass in Germany not through her homegrown movement 
but through Soviet tanks rolling into Berlin. Those tanks emanated from Stalin's dictatorship; Luxemburg was right to worry about a vanguard modelled on industrial discipline. What she longed for remains so often elusive: a movement firm enough to gain power yet supple enough to wield it humanely.

Now, stop and go back, and reconsider those apparently kneeling before spontaneous resistance, against the strictures of governance. Synthesise the dialectic. Fanon also warned against the "cult" of spontaneity $(1961 / 1963,130)$ and stressed that the "enlightening of consciousness" necessary for liberation is "only possible within the framework of an organisation, and inside the structure of a people" (142). He held that spontaneous energies must find institutional cohesion. C.L.R. James affirmed, in his final interview, "I believe you must have an organisation" (Fitzpatrick 1989) in the Leninist sense. He celebrated the Paris Commune as a forerunner of the Russian soviets, regarding that uprising as "first and foremost a democracy" (Johnson 1946). And in "Every Cook Can Govern", an essay that took its title from a phrase of Lenin's, James recommends to workers the ancient Athenian method of ruling by sortition, selecting authorities from the citizenry by lot. The anticolonial organisation, in this light, must be creative and accountable, reaching into the lives of those who are self-governing and also outward as a model to others. As Adom Getachew (2019) documents, the independence movements James helped to inspire sought not just nation states but a new order of global governance.

Grace Lee Boggs was long a fellow traveller with James in the factions and divisions of sectarian Marxism, a student and friend of Third World revolutionaries (Boggs and Boggs 1974; Boggs 1998/2016). She and James Boggs thought their way into a "politics of personal development" (King 2017) that rejected partisan orthodoxies in favour of a more iterative "dialectical humanism", in which political visions and the people who hold them evolve together through struggle. From the systems thinker Margaret J. Wheatley came Boggs's frequent affirmation of "critical connections" over "critical mass" (Boggs and Kurashige 2012, 50) - a conviction that the germ of seismic change lies in the thick relationality of how people choose to self-organise day to day. She drifted from Leninism, but the imperative of self-governance only deepened.

Later in life, Boggs's attention turned from achieving state communism to commoning, the work of people continually discovering what they are seeking to achieve by stewarding shared projects and resources. She became a mentor to veterans of the 2011 Occupy Wall Street and its "leaderless" travails. After her passing, Rodrigo Nunes (2021, Chapter 1) in Brazil envisions post-2011 movement organisation with naturalistic language like "nebula" and "ecology". He confesses attempting to recuperate a kind of vanguardism, a "networked Leninism" - before concluding with an insistence that above all activists should "think and act ecologically" (Conclusion).

In Boggs we see the origins of passages about mycelia and butterflies and trees in the writing of her disciple adrienne maree brown (2017). brown's "emergent strategy" for activists revels not in conflict with corporate opponents but in apparitions of friendship in online threads and tips for weaving consensus processes. Seeking to transcend "protest politics", Boggs described her mentorship of younger organisers as

projecting and initiating struggles that involve people at the grassroots in assuming the responsibility for creating new values, truths, infrastructures, and institutions that are necessary to build and govern a new society (Boggs and Kurashige 2012, 68). 
Fred Moten acknowledges the Boggses' influence as an example of unpayable debts (Harney and Moten 2013, 153). What he and Harney offer in place of governance is "study", a term of art that is also resolutely plain, in reference to the learning and planning that takes place among groups of people in spaces that are ungovernable by reigning institutions. Like the maroons of Saint-Domingue or the American South, study surely involves an order of its own, apart from the colonial university, a practice of insurgent self-rule. The maroons of study, for Harney and Moten, are never-settled communities of criminal exodus. But their maroons undertake "fugitive planning". They study to plan, they plan so they can find the space and time to study. To do either, and therefore both, there must be something of the self-governance Harney and Moten seem to disavow.

These anticolonial thinkers see the trouble with governance in the sense of governmentality, a back-door aid to domination. And yet they also assert the otherwise troublesome kind of self-governing, the kind that is ungovernable and opaque and maroon from the vantage point of the imperial capitals - and, now, of the colonial platforms. The next section recalls how platforms have enabled their users to feel ungovernable and powerful for a time. But without the means of self-governing, those sensations have been fleeting.

\section{Virality as a Colonising Strategy}

I once entered the office of a labour organiser to find her there, head in her hands. She was running a campaign in the ever-shifting, just-in-time, atomised theatre of urban retail. Why so down? The workers were migrating to Instagram. At least on Facebook, you could corral them into groups, you could post updates. On Instagram, every message had to be hilarious or enraging or gorgeous if you wanted it to reach them. Sometimes the information an organiser needs to share is not any of those. But isn't it still important?

Without persistent groups or organisations, Instagram's eminent form of shared experience is the viral image, which circulates an affective impression of shared experience. To spread, the image must be the kind of image that would spread, according to the tastes of the poster's followers and the secret churning of the platform's engineering. An announcement for next week's union meeting may not qualify. An organiser trying to strengthen workers' bonds isn't interested in infecting them like a virus.

The rise of ubiquitous social media rode on waves of protest, from the Battle of Seattle to the Arab Spring. Individual voices, linked with hashtags, seemed to herald collective liberation (Papacharissi 2015). And yet, despite the outpourings of promise and hope and near-term victories, those digitally mediated uprisings have fallen under the police of Mohamed Morsi and the bombs of Bashar al-Assad, the famines of the Yemeni civil war and the warlords of Libya. 'Pirate' political parties arising out of online protest have tended to collapse upon their first encounter with power, if they ever get there.

At the Occupy Wall Street encampment in 2011, reporters would arrive and be transfixed by the media centre - the nerve centre, the centre of power because it was media (Schneider 2013, 36). And media was powerful indeed, as it drew thousands upon thousands of people into what began as a small, precarious protest. Videos of police attacking activists, in particular, bred sympathy and participants, and a feeling that the movement might be on the brink of sparking some kind of revolution. At least at first. By the following year, the videos didn't work the same way. As an activist monitoring the analytics data noticed at the time, "Riot porn is losing its luster for mass 
online consumption" (Schneider 2012). As the social-media attention waned, so did the movement's confidence.

The likes of Vladimir Putin, Donald Trump, and Xi Jinping discovered how to outlast digital insurgencies, obscuring outbreaks of dissent under a deluge of obfuscation. Spontaneity is a commodity online, and empires can produce it for themselves.

Experience with multitudinous networks has led their early enthusiasts to call for more self-ordering. Hardt and Negri (2017) clarify their embrace of leaderless movements by stressing the need for "the institutionalization of free and democratic forms of life", organised enough to be "able to take hold of the common" (xx). To Zeynep Tufekci (2017), the networked "signal" of movements can be self-defeating without organisational "capacity".

The classic strategy of imperial domination - divide et impera, divide and conquer - proposes to dominate by training subjects to feel an illusion of power through their conflicts with one another. On colonial platforms, too, users direct their energy for and against each other, gaining influence and affirmation through their jousts and, in so doing, identifying themselves ever more deeply with the non-transferable reputation they obtain on the platforms. Virality is fleeting if it ever happens, but the possibility is there, so we pursue it. Before long we have recapitulated the final scene of the 1954 McCarthyist blockbuster On the Waterfront, in which the dockworkers flee from their union's problems into the arms of the boss, newly able to experience their collective exploitation as individual liberation.

Virality seems to offer a sort of ungovernability in the relentless freedom to say anything and constitute momentary publics. But the economy of virality does not bow to the drudgery or urgency of self-organisation. Platforms optimise for 'engagement' through chatter - not decision, resolution, or consensus. Community control is not in the specification. In the following section I will introduce my plea for community control through governable stacks.

\section{Spinning Wheels and Governable Stacks}

The actor Charlie Chaplin met Mohandas K. Gandhi in London in 1931. Chaplin later recalled that, after a bout of anxiety about what to say, he began, "I am somewhat confused by your abhorrence of machinery" (Chaplin 1966, 373; Desai 1931). Gandhi explained that machines were not the enemy, the empire was. He spun his own cloth to resist the British textile monopoly, and even in solidarity with the mill-workers in England. Three years later, after hearing a story about factory conditions in Detroit, Chaplin had shed his earlier confusion and began work on the classic satire of mechanised capitalism, Modern Times (Chaplin 1966, 415).

Today Gandhi holds a tenuous place in the anticolonial canon. His ever-evolving vision of national liberation frequently fell short of liberation for all, particularly people facing subjugation by race and caste (Rao 2009; Roy 2017; Mishra 2018). His demands on followers, beginning with his own family, could be ruthless and cruel. I do not seek to engage in further pursuit of his deification. And yet Gandhi was an anticolonial leader who was both especially resolute in articulating a strategy of self-governance and successful in the work of dispatching foreign occupiers. His success inspired more struggles, from Soweto to Alabama. And his teachings combined that confusing attitude toward machinery with the practice of creative self-governance.

The flag of the pre-independence Indian National Congress had a spinning wheel at its centre, the symbol of Gandhi's "constructive programme": self-rule, or swaraj, as the basis of both resistance and the society that would follow. After independence the flag lost the spinning wheel, but by law it still must be made of hand-spun cloth. Gandhi 
hoped that self-sufficient and self-governing people would become ungovernable to colonisers. He regarded this, not the more famous and visible acts of protest, as the heart of his politics. "Civil Disobedience without the constructive programme", he wrote, "will be like a paralysed hand attempting to lift a spoon" (Gandhi 1941, 29). The link between self-governance and resistance was so strong for Gandhi that he regarded his personal self-control, even in diet and sexuality, as intertwined with the fate of the independence movement. For him the spinning wheel represented a reconstructed Indian masculinity, along with an affirmation of indigenous arts (Brown 2009). Against the liberal view, he came to see democracy as more a task of self-sacrifice than of selfinterest. Observing the dangers that heavy industry poses to the planetary ecology and economic sanity, he was interested in what he saw as technologies better suited for community governance (Garg and Camp 2012; Fuchs 2019, 257). The spinning wheel was a cipher to convey the centrality of self-governance to his strategy for struggle, in the guise of a governable tool.

The spinning wheel remains a cipher and a site of conflict, an everyday technology summoned to a contest over the meaning of democracy. Despite having political ties with Gandhi's assassin, the Hindu nationalist prime minister Narendra Modi promotes homespun cloth and has done photo-ops operating a spinning wheel. Modi has meanwhile shuttered boards that gave artisans a voice in policy under the slogan "Minimum Government and Maximum Governance" (Vincent 2020). The technology itself does not guarantee self-governance, but it can be the symbolic base from which ever-enlarging acts of self-governance defeat an empire.

In the spirit of the technological cipher I propose the pursuit of "governable stacks": an orientation toward ungovernable organising under digital colonialism.

The geek-colloquial meaning of stack, in the most relevant sense, is a set of interoperating hardware and software. Benjamin H. Bratton (2016, xvii) goes further, describing the stack as "a new architecture for how we divide the world into sovereign spaces". Its layers come with intersecting relations of dependency, along with emergent freedoms. A stack might include all that enables one to use a social media service, for instance: the server farms, the corporation that owns them, its investors, the software the servers run on, the secret algorithms that analyse one's data, the mobile device, its accelerometer sending biometric data to the server farm, the network provider, the backdoor access for law enforcement, and so on. The layers of a stack might further include the sun or coal powering it, the wars fuelled by rare-earth mining, and the mythologies and rituals that dictate what people in it will tolerate. Each layer is in fact multiple layers, and layers build on each other.

Before governable stacks were the topic of this article, they were an experience for me, particularly through an organisation in which I have been an anecdotal participantobserver for a decade. May First Movement Technology (mayfirst.coop) is a cooperative that provides web hosting, cloud services, and public education for a 850-strong membership composed largely of activist organisations in the United States and Mexico (Lopez et al. 2007). Through the tools May First offers, I have been able to move much of my daily computing away from companies that surveil and extract into servers I co-own and govern, running commons-based software. I have formed relationships with the people who maintain these services and participated in decision-making over bilingual conference calls and online ballots. I learn about new tools from fellow members, and we sponsor events that teach people outside our membership how to challenge the power of big tech in their lives and their communities. Akin to the slow food 
movement, this is slow computing (Schneider 2015), its pace measured not by bandwidth or processing speed but by the attention to the social dimensions of everyday practice.

While Silicon Valley elites escape to phone-free retreats (Marantz 2019) and agonise about their children's exposure to screens (Bowles 2018), May First offers no such "abhorrence of machinery" (Chaplin 1966, 373). It does not accept the false choice between addictive, surveillance-addled apps and a fantasy of returning to some blissful innocence. Instead, members share technologies that do what they need and that they can reasonably control. These technologies, and the self-governance we surround them with, are our stack. May First does not demand that you 'learn to code', or otherwise trade traditional knowledge for digital expertise. For me, being part of a governable stack like May First has unlocked political possibilities. The experience motivated years of working to build governable stacks elsewhere, because I know that it can be done. I poured myself into developing alternative ownership models like "platform cooperatives" (Schneider 2018) and "exit to community" (Mannan and Schneider 2021) that are better suited to making tech governable. With time, ungovernable stacks have come to feel like foreign lands. I may use them, but they never feel like home.

Governable stacks are cyborg assemblages of inter-operating technology, in symbiosis with human relationships (Haraway 1991; Puar 2012). Those relationships organise power, in partnership with the technology more than through domination over it. We learn with each other, and we learn with the machines, which take on life of their own - through their own intelligence, or that which we affectionately project onto them. In the sense of Grace Lee and Jimmy Boggs's dialectical humanism, governable stacks invite the people who use them to change their relationship with technologies, to imagine different sorts of technologies, and to be changed themselves.

Perhaps governability can be achieved by reconfiguring tools that already exist; perhaps it is necessary to make new ones. Tiziana Terranova (2014), who has proposed the complementary idea of a "red stack", writes that insurgent stacks become "new platforms through a crafty bricolage of existing technologies, the enactment of new subjectivities through a detournement of widespread social media literacy". Older technologies may be better suited to this than newer ones (Maxigas and Latzko-Toth 2020). Even the colonial platforms can be repurposed - as the Algerian writer Kateb Yacine said of the French language - as spoils of war. The lifeblood of the governable stack is not any claim to innovation but the self-governance that flows through it. What emerges from there is the point.

The Guifi.net community Internet network in Catalonia (guifi.net) became the condition of possibility for a suite of "community cloud" services deployed through it (Selimi et al. 2015). FairTEC ( $\underline{\text { fairtec.io) }}$ ) combines into one product a stack of preexisting services across three European countries: a sustainably manufactured smartphone, a non-commercial operating system, a cooperative telecom, and a cooperative phone rental company. The developers of the CommonsCloud (commonscloud.coop) see their shared technology as only one layer of a larger community stack, which also includes "social" and "discursive" layers - the context and substance of their self-governance. Layers form over time, too. Governable stacks of the past lurk in the archaeology of colonial systems through legacies like Indymedia, an activist social network whose participatory servers and software prefigured the corporate "Web 2.0" (Pickard 2006). Indymedia itself drew from decades of organising among activist communityradio stations, particularly in Latin America (Ruiz Martinez 2021). There can be no one governable stack - only many, whose archipelagos of commoning enable each other and give rise to more. 
Technologists seeking alternative visions have often gravitated to the Free Software and Open Source movements, which employ creative licensing to enable the sharing of accessible and modifiable code. These movements have been successful in terms of the sheer volume of widely used software in their commons. But their emphasis on the freedoms of individual users, as well as of corporations, has privileged those with the technical know-how to take advantage. The software commons has spawned operating systems that fly in military jets and databases that aid in the imprisonment of asylum seekers (Ehmke 2020). In the name of freedom, too, developers have harboured sexism and other forms of exclusionary culture (SSL Nagbot 2016). Governable stacks should prioritise community accountability alongside individual freedom.

Another emerging strategy for challenging digital colonialism has come from within. Employees at Silicon Valley giants have achieved reforms by organising against certain ethical outrages at their workplaces (Tarnoff 2020). Yet there are limits to what these campaigns are likely to achieve, since these workers are invested - often literally, through stock options - in the basic business models of their employers. Employees' actions can present the impression that their protest cleanses the colonial tools they produce. Governable stacks do not seek merely to improve the occupier. "Decolonization is not an 'and"', as Tuck and Yang (2012) put it. "It is an elsewhere" (36).

Experiences with governable stacks introduce us to possible elsewheres. The spinning wheel was an elsewhere, the invention of a democratic India. May First Movement Technology is an elsewhere for its members, who in turn become part of its learning and evolving. Collectives, families, and movements can assemble and adjust their stacks over time, wherever possible seeking to make their technological lives ever more governable. I next turn to strategies to guide the process of doing so.

\section{Governable Strategy}

May First is infinitesimally small by the standards of the tech economy. "Goldman Sachs doesn't care if you're raising chickens", as the political theorist Jodi Dean (2011) has said. It's a reminder for anyone tempted to see too much potential in personal practices, technological or otherwise. But spinning wheels are small, too, and they helped drive away the British Empire.

adrienne maree brown (2017) credits Grace Lee Boggs for helping her see that (her emphasis) "what we practice at the small scale sets the patterns for the whole system". She explains this in a chapter called "Fractals", which recalls how she shifted her activism to better reflect her political values in daily practice. Fractals are mathematical phenomena, frequent in nature, whose patterns at smaller scales repeat at larger scales. They are appealing and widely used as a metaphor, being both mathematically precise in theory and conveniently vague when applied to human affairs. Those like brown and Boggs who apply fractal-talk to politics exercise a kind of faith. To make good on that faith, there must some linkage, some strategy, that connects self-governance from the scale of small communities to the larger societies those community seek to transform.

There was a fractal in the free maroons of Saint-Domingue who stormed down from their mountains into combat with French troops so the whole island could be free. There was a fractal in the spinning wheel on the Indian National Congress flag, extending from a traditional practice to an eventual industrial policy. These chickens came to roost because they were part of a strategy that involved organised confrontation with colonial power. Self-governing became a challenge, a threat. In even small experiments, governable stacks can begin to normalise the otherwise elusive fact that 
better ways of organising technology are possible. Carefully chosen practices sever habits of dependency on the systems we seek to resist.

For governable stacks to be truly governable, they must also become powerful. They must spread and erode the colonial grip. Exit alone is not an option; against ubiquitous networks, governability entails confrontation. To that end, I propose three interlocking strategies: sovereignty, democracy, and insurgency.

\subsection{Sovereignty}

It is an uncomfortable matter of fact that nowhere has been so successful a counterweight to the power of Silicon Valley as China. The country has not only barred certain data-colonising companies with its 'Great Firewall' but has cultivated comparably ubiquitous Internet firms, using comparably invasive colonial practices to produce platforms that are at once hyper-capitalist and dominated by state interests (Chu 2017; Hong 2017). And yet China's policy of sovereignty shows that dependence on hostile stacks is not inevitable.

Rather than trading one colonial power for another, Western Europe has sought a high road in demanding privacy regulations and investments in commons-based technology (Lemley 2020). Projects such as the Sovereign Cloud Stack (scs.community) seek to supplant reliance on corporate walled gardens with globally replicable, locally deployed tools. Several European governments have adopted and funded free/opensource software like the Matrix (matrix.org) messaging protocol and NextCloud (nextcloud.com), a file-sharing platform. Countries far from the power centres, like Uganda and Lebanon, have experimented with imposing taxes on the use of foreign social media (Boxell and Steinert-Threlkeld 2019). Although such efforts have been widely perceived as acts of repression more than solidarity, similar policies could be used for different goals. Echoing the Cold War-era Non-Aligned Movement among countries caught between the United States and the Soviet Union, some have been calling for a "digital non-aligned movement" that asserts many diverse sovereignties against the duelling forces of Silicon Valley and Shenzhen (Freuler 2020; Mejias 2020).

Sovereignty need not be solely the purview of nation states. The discourse of digital sovereignty has been particularly important among indigenous communities whose members are used to seeing their pre-digital sovereignty effaced; they have developed governable stack-layers such as tribal broadband lines (Blackwater 2020), cryptocurrencies (Tekobbe and McKnight 2016), data governance (Carroll et al. 2020), and linguistic autonomy (Pinto 2018). Amelia Winger-Bearskin (2020) draws on the Haudenosaunee practice of wampum agreements to propose "ethical dependencies" in software; these would encode and enforce certain commitments up and down the stack. Laying claim to collective sovereignty is central to such practices. Glen Sean Coulthard (2014) challenges the "colonial politics of recognition" - when people accept their colonisers' definition of their sovereignty, rather than their own - to insist on more autonomous forms of self-determination. He describes how tribal nations can produce sovereignty through "community-scale activities" such as cooperatives and assemblies in everyday life (68). The indigenous organiser Berta Cáceres, before her murder by Honduran paramilitaries, denounced the pseudo-democracy of political representatives but affirmed the "decisive" democracy possible through poor people's movements (Castellanos and Pine 2020).

Sovereignty can occur at levels ranging from the network backbone to last-mile connections, up through the hardware and software of devices, to the collaboration tools in the cloud. Sovereignty looks like a user-owned cooperative or a city providing connectivity, or like Douglass (douglass.io), an operating system whose apps take their 
names from icons of Black liberation. The tech publication The Markup has paid a "privacy tax" by developing its own software that protects user data rather than adopting the standard surveillance-based offerings (Angwin 2020). For Archive of Our Own (archiveofourown.org), a fan-run fandom repository, sovereignty puts creators in control of how they publish and protects their work against copyright overreach. What makes technology sovereign is when its stewards are the people who depend on it, protected from outside control by any legal or extra-legal means available. The data, the algorithms, and the interfaces are for their users, rather than acting surreptitiously against them.

\subsection{Democracy}

The other side of sovereignty is participatory democracy - its guarantor and its everyday practice. Here we resist the temptation of autocratic vanguardism by designing governable stacks to be accountable and alive. The style of democracy may be that of the Debian operating system, a constitutional republic of coders (debian.org/devel/constitution), or like the Ethical Source Movement's vision of many collectives deciding on the ethical limits of how their software can be used (ethicalsource.dev). Digital democracy is beginning to have dedicated tools - from smaller-group decisions on Loomio (loomio.org) to the scale of cities or countries through Barcelona's Decidim (decidim.org) or Polis (pol.is), which is employed by the government of Taiwan (Stempeck 2020). Platform cooperatives practice democracy at the level of the company, such as at Stocksy United (stocksy.com), co-owned by artists in dozens of countries (Schneider 2018). On a network scale, the federated social network Mastodon was able to counteract an incursion by the alt-right platform Gab, as it did earlier with Islamic State accounts - through self-organised activity by server administrators and app developers (Caelin 2020). Countering hate speech doesn't need to depend on the might of a global monopoly; it can be tangible and empowering.

Practices of local democracy from the Global South have been migrating into governable online tools. Participatory budgeting practices originating from Porto Alegre, Brazil (Cabannes 2004), have appeared in apps like Cobudget (cobudget.co) and Decidim. A founder of an experimental political party in Argentina, Partido Red, has applied the same logic of "liquid democracy" to a blockchain-based governance platform, Democracy Earth (democracy.earth). Mexico City's 2016 exercise in crowdsourcing its constitution has been studied as a model around the world.

Digital democracy has the potential to evolve rapidly and creatively. People can participate in far more rapid and fine-grained ways than was possible when the prevailing regimes of corporate and state governance first appeared. Organisational designs that work well could become part of a governance commons, enabling other groups to adopt, adapt, and share them back into the common pool (Schneider et al. 2021). In this way, small-scale accountability can spread, and it can creep into larger and larger kinds of communities, demonstrating that colonial control was never necessary. The more we demand and practice the arts of self-governing, the harder we are for someone else to govern.

\subsection{Insurgency}

The spinning wheel stood for household autonomy, but it was also defiance against British rule. Governable stacks must be similarly insurgent. Some of the earliest online social media emerged through Indymedia's coverage of anti-capitalist protests. Twitter has its roots in technology for coordinating street protests (Costanza-Chock 2020, 
Chapter 3). While investors and accelerators receive frequent credit for innovation, insurgency is just as much a source of it.

Insurgency might mean challenging government subpoenas of member data, as May First has done, or facilitating leaks about abuses of power. Resistance might take the form of what the Catalan Integral Cooperative calls "economic disobedience" (cooperativa.cat/economic-disobedience), which includes refusing to pay unjust taxes or interest. Insurgents might choose not to submit the data of a friendship to the social graphs of colonial platforms, or to actively deceive those platforms, just as the Tor network (torproject.org) disguises its users' locations. Like Copwatch groups or the Driver's Seat Cooperative (driversseat.sco), insurgents can do data collection on the colonisers, sousveillance from below (Browne 2015).

To the extent that establishing the expansionist, slaveholding republic of the United States was also an anticolonial conflict, it relied on self-governance as resistance. The colonists organised through a Continental Congress, which extracted lessons from the Haudenosaunee nations - yes to confederation, no to matriarchal authority - to prefigure a future government. After independence, Alexis de Tocqueville (1840/2006) observed how the flourishing of civic associations energised the politics of the fledgling republic. Successful poor people's struggles against the country's wealthy elites, from the 19th-century Populists (Goodwyn 1978) to the 20th-century movements for Black power (Nembhard 2014), grew out of tangible collective organising in labour unions and cooperatives.

Insurgents might use colonial platforms for education and organising. They might spread viral messages and enjoy themselves. But if they have governable stacks to go back to, they are more than just subjects. They are maroons, with swamps and forests of their own.

\section{Conclusion}

The university lab I direct has sought to manage a stack as an exercise in pedagogy and space-making. We operate our own suite of free/open-source software for chat, file-sharing, polls, websites, and multiplayer games. Students use these to collaborate, and those who are interested can learn to be co-administrators.

The lab's 'cloud' is an ever-evolving experiment, still short of what I would hope for from a governable stack. Most students have yet to play much of a role in decisionmaking or design. The stack also resides on the servers of a far-away hosting company, though I hope someday that students can hear the hum of the machines running their tools. And I question whether it is challenging any colonisers. The stack's hiccups often seem to remind students why they prefer systems that powerful companies manage for the price of their data. At least so far, I fear that our steps toward governability have taken us at least as many steps back. We feel alone in what we are doing, and that makes the frustrations all the more demoralising. It becomes easier for any one group to make its stack governable when others are doing the same.

The urgency of forming governable stacks stems not only from tech giants and surveillance states. Groups dedicated to racism and authoritarianism have become particularly intentional about their network stacks, migrating to dedicated platforms such as Stormfront, Parler, and Gab as more mainstream networks remove them (Bevensee 2020). Will governable stacks become the speciality of reactionaries? The stack has already become a field of conflict, like the spinning wheel.

The anticolonial tradition suggests that resistance to digital colonialism will depend on sustaining resistance in everyday life. I have proposed governable stacks as a strat- 
egy for doing this. Governable stacks organise technology that bends with the ungovernable contortions of self-governing life - technology for communities that can be, as Rosa Luxemburg (1904) hoped for, "supple as well as firm".

\section{References}

Ali, Syed Mustafa. 2016. A Brief Introduction to Decolonial Computing. XRDS: Crossroads, the ACM Magazine for Students 22 (4): 16-21. https://doi.org/10.1145/2930886

Anderson, William C. 2020. Ungovernable: An Interview with Lorenzo Kom'boa Ervin. Black Rose/Rosa Negra Anarchist Federation, September 11. Accessed December 19, 2021. https://blackrosefed.org/ungovernable-interview-lorenzo-komboa-ervin-anderson/

Angwin, Julia. 2020. Paying the Privacy Tax. The Markup, December 12. Accessed December 19, 2021. https://www.getrevue.co/profile/themarkup/issues/paying-the-privacy-tax298830

Avila, Renata. 2020. Against Digital Colonialism. In Platforming Equality: Policy Challenges for the Digital Economy. Autonomy, September 22. Accessed December 19, 2021. https://autonomy.work/portfolio/platformingequality/

Benjamin, Ruha. 2019. Race After Technology: Abolitionist Tools for the New Jim Code. Medford, MA: Polity.

Bevensee, Emmi. 2020. The Decentralized Web of Hate. Rebellious Data LLC. Accessed December 19, 2021. https://rebelliousdata.com/wp-content/uploads/2020/10/P2P-HateReport.pdf

Bird, Stewart, Rene Lichtman and Peter Gessner (dirs.). 1970. Finally Got the News. Produced in association with the League of Revolutionary Black Workers. New York: Icarus Films. Accessed December 19, 2021. http://icarusfilms.com/if-fin

Blackwater, Darrah. 2020. Indigenize the Internet: How to Close the Digital Divide by Respecting Tribal Sovereignty. Presentation. Native Nations Institute, University of Arizona, April 29. Accessed December 28, 2021. https://nnigovernance.arizona.edu/darrah-blackwater-indigenize-internet-how-close-digital-divide-respecting-tribal-sovereignty

Boggs, Grace. 1998/2016. Living for Change. Minneapolis: University Of Minnesota Press.

Boggs, Grace Lee and Scott Kurashige. 2012. The Next American Revolution: Sustainable Activism for the Twenty-First Century. Berkeley, CA: University of California Press.

Boggs, James and Grace Lee Boggs. 1974. Revolution and Evolution in the Twentieth Century. New York: Monthly Review Press.

Bowles, Nellie. 2018. A Dark Consensus About Screens and Kids Begins to Emerge in Silicon Valley. The New York Times: Style, October 26. Accessed 19 December 2021. https://www.nytimes.com/2018/10/26/style/phones-children-silicon-valley.html

Boxell, Levi and Zachary Steinert-Threlkeld. 2019. Taxing Dissent: The Impact of a Social Media Tax in Uganda. September 9. Accessed December 19, 2021. http://arxiv.org/abs/1909.04107

Bratton, Benjamin H. 2016. The Stack: On Software and Sovereignty. Cambridge, MA: MIT Press.

Brown, R. M. 2009. Spinning Without Touching the Wheel: Anticolonialism, Indian Nationalism, and the Deployment of Symbol. Comparative Studies of South Asia, Africa and the Middle East 29 (2): 230-245. https://doi.org/10.1215/1089201X-2009-006

Browne, Simone. 2015. Dark Matters: On the Surveillance of Blackness. Durham, NC: Duke University Press.

brown, adrienne maree. 2017. Emergent Strategy: Shaping Change, Changing Worlds. Chico: AK Press.

Cabannes, Yves. 2004. Participatory Budgeting: A Significant Contribution to Participatory Democracy. Environment and Urbanization 16 (1): 27-46.

https://doi.org/10.1177/095624780401600104 
Caelin, Derek. 2020. Decentralized Social Networks Vs. The Trolls. Presented at the ActivityPub Conference. Accessed December 19, 2021. https://conf.tube/videos/watch/d8c8ed6979f0-4987-bafe-84c01f38f966

Canella, Gino. 2018. Racialized Surveillance: Activist Media and the Policing of Black Bodies. Communication, Culture and Critique 11 (3): 378-398. https://doi.org/10.1093/ccc/tcy013

Carroll, Stephanie Russo, Ibrahim Garba, Oscar L. Figueroa-Rodríguez, Jarita Holbrook, Raymond Lovett, Simeon Materechera, Mark Parsons et al. 2020. The CARE Principles for Indigenous Data Governance. Data Science Journal 19 (1, 1): 43. https://doi.org/10.5334/dsj-2020-043

Castellanos, Asís and Adrienne Pine. 2020. Berta Cáceres in Her Own Words. Toward Freedom, July 29. Accessed December 19, 2021. http://towardfreedom.org/story/berta-caceres-in-her-own-words/

Castells, Manuel. 2015. Networks of Outrage and Hope: Social Movements in the Internet Age. Cambridge: Polity.

Chaplin, Charlie. 1966. My Autobiography. New York: Pocket Books. Accessed December 20, 2021. http://archive.org/details/myautobiographyi00chap

Chu, Cho-Wen. 2017. Censorship or Protectionism? Reassessing China's Regulation of Internet Industry. International Journal of Social Science and Humanity 7 (1): 5. http://ijssh.org/vol7/790-MC26.pdf

Cooper, Frederick. 2005. Colonialism in Question: Theory, Knowledge, History. Berkeley, CA: University of California Press.

Costanza-Chock, Sasha. 2020. Design Justice: Community-Led Practices to Build the Worlds We Need. Cambridge, MA: The MIT Press.

Couldry, Nick and Ulises A. Mejias. 2019a. Data Colonialism: Rethinking Big Data's Relation to the Contemporary Subject. Television \& New Media 20 (4): 336-349. https://doi.org/10.1177/1527476418796632

Couldry, Nick and Ulises A. Mejias. 2019b. Making Data Colonialism Liveable: How Might Data's Social Order Be Regulated? Internet Policy Review 8 (2). https://doi.org/10.14763/2019.2.1411

Coulthard, Glen Sean. 2014. Red Skin, White Masks: Rejecting the Colonial Politics of Recognition. Minneapolis: University of Minnesota Press. https://muse.jhu.edu/book/35470

de Tocqueville, Alexis. 1840/2006. Democracy in America. Translated by Henry Reeve. Project Gutenberg. https://www.gutenberg.org/ebooks/815 \& https://www.gutenberg.org/ebooks/816

Dean, Jodi. 2011. The Communist Horizon (Television interview). Presented at the NoSpace, Brooklyn, NY, July 28. Accessed December 20, 2021. https://vimeo.com/27327373

Desai, Mahadev. 1931. Charlie Chaplin Meets Gandhiji. Young India, October 8. Accessed December 20, 2021. https://www.theleaflet.in/gandhiii-inspired-charlie-chaplin-to-makehis-classic-movie-modern-times/

Duarte, Marisa Elena, Morgan Vigil-Hayes, Sandra Littletree, and Miranda Belarde-Lewis. 2019. 'Of Course, Data Can Never Fully Represent Reality': Assessing the Relationship Between Indigenous Data and IK, TEK, and TK. Human Biology 91 (3): 163-178. https://doi.org/10.13110/humanbiology.91.3.03

Ehmke, Coraline Ada. 2020. A Six-Month Retrospective on Ethical Open Source. Model View Culture, April 16. Accessed December 20, 2021. https://modelviewculture.com/pieces/asix-month-retrospective-on-ethical-open-source

Eubanks, Virginia. 2018. Automating Inequality: How High-Tech Tools Profile, Police, and Punish the Poor. New York: St. Martin's Press.

Fanon, Frantz. 1961/1963. The Wretched of the Earth. New York: Grove Weidenfeld. 
Fitzpatrick, John. 1989. 'You Never Know When It's Going to Explode'. Living Marxism, April. Accessed December 20, 2021. https://www.marxists.org/archive/jamesclr/works/1989/04/interview.html

Freuler, Juan Ortiz. 2020. The Case for a Digital Non-Aligned Movement. openDemocracy, June 27. Accessed December 20, 2021. https://www.opendemocracy.net/en/oureconomy/case-digital-non-aligned-movement/

Fuchs, Christian. 2019. M. N. Roy and the Frankfurt School: Socialist Humanism and the Critical Analysis of Communication, Culture, Technology, Fascism and Nationalism. tripleC: Communication, Capitalism \& Critique 17 (2): 249-286. https://doi.org/10.31269/triplec.v17i2.1118

Gandhi, M. K. 1941. Constructive Programme: Its Meaning and Place. Ahmedabad: Navajivan Publishing House. Accessed December 20, 2021. https://www.gandhiheritageportal.org/mahatma-gandhi-books/constructive-programme-its-meaning-and-place

Garg, Vaibhav and L. Jean Camp. 2012. Gandhigiri in Cyberspace: A Novel Approach to Information Ethics. ACM SIGCAS Computers and Society 42 (1): 9-20. https://doi.org/10.1145/2422512.2422514

Garza, Alicia. 2020. The Purpose of Power: How We Come Together When We Fall Apart. New York: One World.

Getachew, Adom. 2019. Worldmaking After Empire: The Rise and Fall of Self-Determination. Princeton, NJ: Princeton University Press.

Goodwyn, Lawrence. 1978. The Populist Moment: A Short History of the Agrarian Revolt in America. New York: Oxford University Press.

Haraway, Donna. 1991. Simians, Cyborgs, and Women: The Reinvention of Nature. New York: Routledge.

Hardt, Michael and Antonio Negri. 2017. Assembly. New York: Oxford University Press.

Harney, Stefano and Fred Moten. 2013. The Undercommons: Fugitive Planning \& Black Study. Wivenhoe: Minor Compositions.

Hong, Yu. 2017. Pivot to Internet Plus: Molding China's Digital Economy for Economic Restructuring? International Journal of Communication 11: 1486-1506. https://ijoc.org/index.php/ijoc/article/view/6105.

Invisible Committee. 2009. The Coming Insurrection. Intervention 1. Los Angeles: Semiotext(e).

Irani, Lilly, Janet Vertesi, Paul Dourish, Kavita Philip and Rebecca E. Grinter. 2010. Postcolonial Computing: A Lens on Design and Development. In Proceedings of the SIGCHI Conference on Human Factors in Computing Systems, CHI '10, 1311-1320. New York: Association for Computing Machinery. https://doi.org/10.1145/1753326.1753522

Iyer, Neema, Garnett Achieng, Favour Borokini and Uri Ludger. 2021. Automated Imperialism, Expansionist Dreams: Exploring Digital Extractivism in Africa. Pollicy (webpage). Accessed December 21, 2021. https://pollicy.org/digitalextractivism/

James, C. L. R. 1938/1989. The Black Jacobins: Toussaint L'Ouverture and the San Domingo Revolution. New York: Vintage Books. Accessed December 21, 2021. http://archive.org/details/blackjacobins00clri

James, C. L. R., Grace C. Lee and Pierre Chaulieu. 1958/1974. Facing Reality. Detroit, Ml: Bewick Editions. Accessed December 21, 2021. https://libcom.org/files/James\%20\%20Facing\%20Reality.pdf

Jandrić, Petar and Ana Kuzmanić. 2016. Digital Postcolonialism. IADIS International Journal on WWW/Internet 13 (2): 34-51.

Jin, Dal Yong. 2013. The Construction of Platform Imperialism in the Globalization Era. tripleC: Communication, Capitalism \& Critique 11 (1): 145-172. https://doi.org/10.31269/triplec.v11i1.458

Johnson, J. R. 1946. They Showed the Way to Labor Emancipation! Labor Action X (11): 4. Accessed December 28, 2021. https://www.marxists.org/archive/jamesclr/works/1946/03/paris-commune.htm 
King, Patrick. 2017. Introduction to Boggs. E-Flux, February 2017. https://www.eflux.com/journal/79/94671/introduction-to-boggs/

Kotliar, Dan M. 2020. Data Orientalism: On the Algorithmic Construction of the Non-Western Other. Theory and Society 49: 919-939. https://doi.org/10.1007/s11186-020-09404-2

Kwet, Michael. 2019. Digital Colonialism: US Empire and the New Imperialism in the Global South. Race \& Class 60 (4): 3-26.

Lebrón Ortiz, Pedro. 2020. Resisting (Meta) Physical Catastrophes Through Acts of Marronage. Radical Philosophy Review 23 (1): 35-57. https://doi.org/10.5840/radphilrev2020219103

Lemley, Mark A. 2020. The Splinternet. Stanford Law and Economics Olin Working Paper \#555. https://doi.org/10.2139/ssrn.3664027

Lenin, Vladimir llyich. 1902/1961. What Is to Be Done? In Collected Works Volume 5: 347530. Moscow: Foreign Languages Publishing House. Accessed December 28, 2021. https://www.marxists.org/archive/lenin/works/1901/witbd/

Levi-Faur, David. 2012. The Oxford Handbook of Governance. Oxford: Oxford University Press. https://doi.org/10.1093/oxfordhb/9780199560530.001.0001

Li, Tania Murray. 2007. Governmentality. Anthropologica 49 (2): 275-281.

Lopez, Alfredo, Jamie McClelland, Eric Goldhagen, Daniel Kahn Gillmor and Amanda B. Hickman. 2007. The Organic Internet: Organizing History's Largest Social Movement. Quetzaltenango: Entremundos Publications. Accessed December 28, 2021. https://mayfirst.coop/files/organicinternet.1.5.pdf

Luxemburg, Rosa. 1904. Organizational Questions of Russian Social Democracy [Leninism or Marxism?]. Neue Zeit. Accessed December 28, 2021. https://rosaluxemburg.org/en/material/2741/

Madianou, Mirca. 2019. Technocolonialism: Digital Innovation and Data Practices in the Humanitarian Response to Refugee Crises. Social Media + Society 5 (3): 1-13. https://doi.org/10.1177/2056305119863146

Mannan, Morshed and Nathan Schneider. 2021. Exit to Community: Strategies for MultiStakeholder Ownership in the Platform Economy. Georgetown Law Technology Review 5 (1). Accessed December 28, 2021. https://georgetownlawtechreview.org/exit-to-community-strategies-for-multi-stakeholder-ownership-in-the-platform-economy/GLTR-05-2021/

Marantz, Andrew. 2019. Silicon Valley's Crisis of Conscience. The New Yorker, August 16. Accessed December 30, 2021. https://www.newyorker.com/magazine/2019/08/26/siliconvalleys-crisis-of-conscience

Maxigas and Guillaume Latzko-Toth. 2020. Trusted Commons: Why 'Old' Social Media Matter. Internet Policy Review 9 (4). Accessed December 28, 2021. https://policyreview.info/articles/analysis/trusted-commons-why-old-social-media-matter

Mejias, Ulises Ali. 2020. To Fight Data Colonialism, We Need a Non-Aligned Tech Movement. Al Jazeera, September 8. Accessed December 28, 2021.

https://www.aljazeera.com/opinions/2020/9/8/to-fight-data-colonialism-we-need-a-nonaligned-tech-movement

Milan, Stefania and Emiliano Treré. 2019. Big Data from the South(s): Beyond Data Universalism. Television \& New Media 20 (4): 319-335. https://doi.org/10.1177/1527476419837739

Mishra, Pankaj. 2018. Gandhi for the Post-Truth Age. The New Yorker, October 15. Accessed December 28, 2021. https://www.newyorker.com/magazine/2018/10/22/gandhifor-the-post-truth-age

Nembhard, Jessica Gordon. 2014. Collective Courage: A History of African American Cooperative Economic Thought and Practice. University Park, PA: Penn State University Press.

Nunes, Rodrigo. 2021. Neither Vertical nor Horizontal: A Theory of Political Organization. New York: Verso Books.

Papacharissi, Zizi. 2015. Affective Publics: Sentiment, Technology, and Politics. New York: Oxford University Press. 
Paul, Sanjukta. 2020. Antitrust as Allocator of Coordination Rights. UCLA Law Review 67 (2): 380-429. Accessed December 28, 2021. https://www.uclalawreview.org/antitrust-as-allocator-of-coordination-rights/

Pickard, Victor W. 2006. United yet Autonomous: Indymedia and the Struggle to Sustain a Radical Democratic Network. Media, Culture \& Society 28 (3): 315-336. https://doi.org/10.1177/0163443706061685

Pinto, Renata Ávila. 2018. Digital Sovereignty or Digital Colonialism? Sur 15 (27): 13.

Puar, Jasbir K. 2012. 'I Would Rather Be a Cyborg Than a Goddess': Becoming Intersectional in Assemblage Theory. philoSOPHIA 2 (1): 49-66. https://muse.jhu.edu/article/486621/pdf

Qiu, Jack Linchuan. 2017. Goodbye iSlave: A Manifesto for Digital Abolition. Urbana, IL: University of Illinois Press.

Rao, Parimala V. 2009. Gandhi, Untouchability and the Postcolonial Predicament: A Note. Social Scientist 37 (1/2): 64-70.

Roy, Arundhati. 2017. The Doctor and the Saint: Caste, Race, and Annihilation of Caste: The Debate Between B. R. Ambedkar and M. K. Gandhi. Chicago: Haymarket Books.

Ruiz Martinez, Luz A. 2021. Indymedia Cancún, Radio Hurakán, and the Sounding of Altermundos Sonoros. Resonance 2 (3): 433-452. https://doi.org/10.1525/res.2021.2.3.433

Schneider, Nathan. 2021. Admins, Mods, and Benevolent Dictators for Life: The Implicit Feudalism of Online Communities. New Media \& Society. https://doi.org/10.1177/1461444820986553.

Schneider, Nathan. 2018. An Internet of Ownership: Democratic Design for the Online Economy. The Sociological Review 66 (2): 320-340.

Schneider, Nathan. 2015. The Joy of Slow Computing. The New Republic, May 20. Accessed December 28, 2021. https://newrepublic.com/article/121832/pleasure-do-it-yourself-slow-computing.

Schneider, Nathan. 2013. Thank You, Anarchy: Notes from the Occupy Apocalypse by Nathan Schneider. Berkely, CA: University of California Press.

Schneider, Nathan. 2012. How OWS' 'Anti-Market Research Analyst' Helps the Movement Go Viral. Waging Nonviolence. July 1. Accessed December 28, 2021. https://wagingnonviolence.org/2012/07/how-ows-anti-market-research-analyst-helps-the-movement-go-viral/

Schneider, Nathan, Primavera De Filippi, Seth Frey, Joshua Z. Tan and Amy X. Zhang. 2021. Modular Politics: Toward a Governance Layer for Online Communities. Proceedings of the ACM on Human-Computer Interaction 5: 1-26. https://dl.acm.org/doi/10.1145/3449090

Selimi, Mennan, Amin M. Khan, Emmanouil Dimogerontakis, Felix Freitag and Roger Pueyo Centelles. 2015. Cloud Services in the Guifi.Net Community Network. Computer Networks 93: 373-388. https://doi.org/10.1016/i.comnet.2015.09.007

SSL Nagbot. 2016. Feminist Hacking/Making: Exploring New Gender Horizons of Possibility. Journal of Peer Production 8. Accessed December 28, 2021. http://peerproduction.net/issues/issue-8-feminism-and-unhacking-2/feminist-hackingmaking-exploring-new-genderhorizons-of-possibility/

Stempeck, Matt. 2020. Next-Generation Engagement Platforms, and How They Are Useful Right Now (Part 1). Civicist, May 12. Accessed December 28, 2021. https://web.archive.org/web/20201101012224/https://civichall.org/civicist/next-generation-engagementplatforms-and-how-are-they-useful-right-now-part-1/

Tarnoff, Ben. 2020. The Making of the Tech Worker Movement. Logic Magazine, May 4. Accessed December 28, 2021. https://logicmag.io/the-making-of-the-tech-worker-movement/full-text/

Tekobbe, Cindy and John Carter McKnight. 2016. Indigenous Cryptocurrency: Affective Capitalism and Rhetorics of Sovereignty. First Monday 21 (10).

https://doi.org/10.5210/fm.v21i10.6955 
Terranova, Tiziana. 2014. Red Stack Attack! Algorithms, Capital and the Automation of the Common. Effimera, March 8. Accessed December 28, 2021. http://effimera.org/red-stackattack-algorithms-capital-and-the-automation-of-the-common-di-tiziana-terranova/

Thaning, Morten Sørensen, Marius Gudmand-Høyer and Sverre Raffnsøe. 2016. Ungovernable: Reassessing Foucault's Ethics in Light of Agamben's Pauline Conception of Use. International Journal of Philosophy and Theology 77 (3): 191-218. https://doi.org/10.1080/21692327.2016.1235987

Thatcher, Jim, David O'Sullivan and Dillon Mahmoudi. 2016. Data Colonialism Through Accumulation by Dispossession: New Metaphors for Daily Data. Environment and Planning D: Society and Space 34 (6): 990-1006. https://doi.org/10.1177/0263775816633195

Tuck, Eve, and K Wayne Yang. 2012. Decolonization Is Not a Metaphor. Decolonization: Indigeneity, Education \& Society 1 (1): 40.

Tufekci, Zeynep. 2017. Twitter and Tear Gas: The Power and Fragility of Networked Protest. New Haven, CT: Yale University Press.

van der Merwe, Rachel Lara. 2020. Imperial Play. Communication, Culture and Critique 14 (1): 37-51. https://doi.org/10.1093/ccc/tcaa012

Vincent, Pheroze L. 2020. Boards That Gave Artisans a Voice Scrapped. The Telegraph India, August 8. Accessed December 28, 2021. https://www.telegraphindia.com/india/all-india-handloom-board-and-the-all-india-handicrafts-board-scrapped/cid/1788527

Vitalist International. 2019. Life Finds a Way. Commune, January 1. Accessed December 28, 2021. https://communemag.com/life-finds-a-way/

Winger-Bearskin, Amelia. 2020. Indigenous Wisdom as a Model for Software Design and Development. Mozilla Foundation, October 2. Accessed December 28, 2021. https://foundation.mozilla.org/en/blog/indigenous-wisdom-model-software-design-and-development/

\section{About the Author}

\section{Nathan Schneider}

Nathan Schneider is an assistant professor of media studies at the University of Colorado Boulder, where he leads the Media Enterprise Design Lab. His most recent book is Everything for Everyone: The Radical Tradition that Is Shaping the Next Economy. 